\title{
Efektifitas Pemberian Modal Usaha Bergulir DP3AKB pada Kelompok Usaha Perempuan Miskin di Kabupaten Aceh Timur
}

\author{
Baihaqi \\ Fakultas Keguruan dan Ilmu Pendidikan, Universitas Samudra, Langsa \\ e-mail: baihaqi10@unsam.ac.id \\ Syardiansah \\ Fakultas Ekonomi, Universitas Samudra, Langsa \\ e-mail: syardiansah@unsam.ac.id
}

\begin{abstract}
This study was conducted on 9 of 23 poor women's business groups in East Aceh District. The purpose of this study was to determine the level of effectiveness of revolving business capital of DP3AKB (formerly known as BPMPKS) for poor women's business groups since 2011-2014. The method used in this study is qualitative with focus group discussion technique. The sample in this study is 9 business groups of poor women scattered in several villages / villages in East Aceh district. The determination of the sample was based on several factors such as the type of business carried out by the recipient group of revolving business capital assistance, the representation of the activity location (cluster), and the amount of business capital received. The informant in the study was the chairman and members of the poor women's business group receiving DP3AKB revolving capital in East Aceh Regency. The analysis tool used is SWOT analysis. The results of the activity show that the revolving business capital given to 9 (nine) women's business groups effectively increases the group's welfare both in terms of income, the increase in the number of group members, the increase in product variants produced by the group and the expansion of the product marketing network.
\end{abstract}

Keywords: Effectiveness, Business Group, Poor Women, Revolving Capital, DP3AKB.

\section{PENDAHULUAN}

Definisi tentang kemiskinan telah mengalami perluasan, seiring dengan semakin kompleksnya faktor penyebab, indikator mau pun permasalahan lain yang melingkupinya. Kemiskinan tak lagi hanya dianggap sebagai dimensi ekonomi melainkan telah meluas hingga dimensi sosial, kesehatan, pendidikan dan politik. Menurut Badan Pusat Statistik, kemiskinan adalah ketidakmampuan memenuhi standar minimum kebutuhan dasar yang meliputi kebutuhan makan dan non makan.

Untuk meminimalisir angka kemiskinan Pemerintahan Kabupaten Aceh Timur tahun 2012-2017 telah menjabarkannya dalam misi yang berbunyi meningkatkan perekonomian daerah melalui optimalisasi potensi basis dan pemberdayaan masyarakat. Hal ini tertuang dalam rencana pembangunan jangka menengah (RPJM) 2012-2017 melalui program peningkatan ekonomi kelompok usaha perempuan miskin yang dilakukan oleh Dinas Pemberdayaan Perempuan, Perlindungan Anak dan Keluarga Sejahtera (DP3AKB).

Program peningkatan ekonomi bagi kelompok usaha perempuan miskin mulai dilakukan sejak tahun 2010 hingga sekarang. Berdasarkan data yang didapatkan dari Dinas Pemberdayaan Perempuan, Perlindungan Anak dan Keluarga Sejahtera (DP3AKB) saat 
ini terdapat 21 kelompok usaha perempuan miskin yang mendapatkan bantuan modal bergulir dari instansi tersebut. Bantuan modal bergulir mulai dicetus sejak tahun 2010 hingga sekarang dengan perputaran modal bergulir di kelompok mencapai 600 juta lebih (sumber: buku rekening kelompok).

Modal bergulir yang dikelola oleh DP3AKB kabupaten Aceh Timur memang dikhususkan bagi kelompok usaha perempuan miskin yang tersebar di beberapa kecamatan dalam kabupaten Aceh Timur. Indikator penerima bantuan modal bergulir bersifat kelompok, dikelola kelompok serta memiliki jangka waktu pengembalian berdasarkan surat perjanjian antara kelompok dan DP3AKB.

Berdasarkan hasil verifikasi dari tim yang dibentuk DP3AKB dengan melibatkan elemen masyarakat sipil dan akademisi, pada tahun 2010 BPMPKS melalui bidang pemberdayaan perempuan telah menyalurkan bantuan modal bergulir kepada 6 kelompok usaha perempuan miskin di Kabupaten Aceh Timur dengan besarnya jumlah modal yang diberikan adalah Rp. 60.700.000/kelompok. Tabel 1 menunjukkan kelompok-kelompok yang mendapatkan bantuan modal bergulir pada tahun 2010 .

Tabel 1. Daftar Kelompok Penerima Modal Bergulir Tahun 2010

\begin{tabular}{llcc}
\hline No & \multicolumn{1}{c}{ Nama Kelompok } & Alamat & $\begin{array}{c}\text { Jumlah Bantuan } \\
(\mathbf{R p})\end{array}$ \\
\hline 1 & Sinar Inong Tani (SITAG) & $\begin{array}{c}\text { Gampong Alue Gadeng } \\
\text { Kecamatan Birem Bayeun }\end{array}$ & 60.700 .000 \\
\hline 2 & Kartini & $\begin{array}{c}\text { Gampong Alue Sentang } \\
\text { Kecamatan Birem Bayeun }\end{array}$ & 60.700 .000 \\
\hline 3 & Bungong Seuke & $\begin{array}{c}\text { Gampong Matang Gleum } \\
\text { Kecamatan Peureulak }\end{array}$ & 60.700 .000 \\
\hline 4 & Baro Phonna & $\begin{array}{c}\text { Gampong Teupin Pukat } \\
\text { Kecamatan Nurussalam }\end{array}$ & 60.700 .000 \\
\hline 5 & RATANA & $\begin{array}{c}\text { Gampong Kuala Geulumpang } \\
\text { Kecamatan Julok }\end{array}$ & 60.700 .000 \\
\hline 6 & Bungong Anggrek & $\begin{array}{c}\text { Gampong Bandar Baru } \\
\text { Kecamatan Indra Makmur }\end{array}$ & 60.700 .000 \\
\hline & & Total & $\mathbf{3 6 4 . 2 0 0 . 0 0 0}$ \\
\hline
\end{tabular}

Sumber: DP3AKB Aceh Timur, 2019

Tabel 2. Daftar Kelompok Penerima Modal Bergulir Tahun 2011

\begin{tabular}{|c|c|c|c|}
\hline No & Nama Kelompok & Alamat & $\begin{array}{c}\text { Jumlah Bantuan } \\
\text { (Rp) }\end{array}$ \\
\hline 1 & Srikandi & $\begin{array}{l}\text { Gampong Alue Sentang } \\
\text { Kecamatan Birem Bayeun }\end{array}$ & 100.000 .000 \\
\hline 2 & Bunga Kasturi & $\begin{array}{c}\text { Gampong Jangat } \\
\text { Kecamatan Darul Ihsan }\end{array}$ & 70.000 .000 \\
\hline 3 & Bungong Sitahon & $\begin{array}{c}\text { Gampong Bayeun } \\
\text { Kecamatan Birem Bayeun }\end{array}$ & 60.000 .000 \\
\hline 4 & Bungong Jaroe & $\begin{array}{l}\text { Gampong Buket Selamat } \\
\text { Kecamatan Sungai Raya }\end{array}$ & 25.000 .000 \\
\hline 5 & Gampong Maju & $\begin{array}{c}\text { Gampong Cot Asan } \\
\text { Kecamatan Nurussalam }\end{array}$ & 40.000 .000 \\
\hline \multicolumn{3}{|c|}{ Total } & 295.000 .000 \\
\hline
\end{tabular}

Sumber: DP3AKB Aceh Timur, 2019 
Tabel 3. Daftar Kelompok Penerima Modal Bergulir Tahun 2013

\begin{tabular}{clcc}
\hline No & \multicolumn{1}{c}{ Nama Kelompok } & Alamat & $\begin{array}{c}\text { Jumlah Bantuan } \\
(\text { Rp) }\end{array}$ \\
\hline 1 & Beutong Caleng & $\begin{array}{c}\text { Gampong Umang Taring } \\
\text { Kecamatan Serba Jadi }\end{array}$ & 25.000 .000 \\
\hline 2 & Putroe Gampong & $\begin{array}{c}\text { Gampong Cot Geulumpang } \\
\text { Kecamatan Peureulak }\end{array}$ & 25.000 .000 \\
\hline 3 & Aroma Tanjung & $\begin{array}{c}\text { Gampong Ketapang Mameh } \\
\text { Kecamatan Idi Rayeuk }\end{array}$ & 25.000 .000 \\
\hline 4 & Baroe Phonna & $\begin{array}{c}\text { Gampong Teupin Pukat } \\
\text { Kecamatan Nurussalam }\end{array}$ & 25.000 .000 \\
\hline 5 & Ratana & $\begin{array}{c}\text { Gampong Kuala Geulumpang } \\
\text { Kecamatan Julok }\end{array}$ & 25.000 .000 \\
\hline 6 & Bungong Kasturi & $\begin{array}{c}\text { Gampong Alue Jangat } \\
\text { Kecamatan Darul Ikhsan }\end{array}$ & 25.000 .000 \\
\hline 7 & Srikandi & $\begin{array}{c}\text { Gampong Julok Tunong } \\
\text { Kecamatan Julok }\end{array}$ & 25.000 .000 \\
\hline 8 & Bungong Jaroe & $\begin{array}{c}\text { Gampong Buket Selamat } \\
\text { Kecamatan Sungai Raya }\end{array}$ & 25.000 .000 \\
\hline 9 & Gaseng Sayang & $\begin{array}{c}\text { Gampong Blang Gleum } \\
\text { Kecamatan Julok }\end{array}$ & 25.000 .000 \\
\hline 10 & Ariga & $\begin{array}{c}\text { Gampong Melidi } \\
\text { Kecamatan Simpang Jernih }\end{array}$ & 25.000 .000 \\
\hline & & Total & $\mathbf{2 5 0 . 0 0 0 . 0 0 0}$ \\
\hline
\end{tabular}

Sumber: DP3AKB Aceh Timur, 2019

Tabel 4. Daftar Kelompok Penerima Modal Bergulir Tahun 2014

\begin{tabular}{llcc}
\hline No & Nama Kelompok & Alamat & $\begin{array}{c}\text { Jumlah Bantuan } \\
\text { (Rp) }\end{array}$ \\
\hline 1 & Bungong Jaroe & $\begin{array}{c}\text { Gampong Nicah Awe } \\
\text { Kecamatan Simpang Ulim }\end{array}$ & 25.000 .000 \\
\hline 2 & Sinar Inong Tani & $\begin{array}{c}\text { Gampong Alue Gadeng } \\
\text { Kecamatan Birem Bayeun }\end{array}$ & 20.000 .000 \\
\hline 3 & Bungong Jaroe & $\begin{array}{c}\text { Gampong Seumatang Keude } \\
\text { Kecamatan Peureulak Timur }\end{array}$ & 25.000 .000 \\
\hline 4 & Bungong Cirih & $\begin{array}{c}\text { Gampong Matang Gleum } \\
\text { Kecamatan Peureulak }\end{array}$ & 20.000 .000 \\
\hline 5 & Uree Miskin & $\begin{array}{c}\text { Gampong Matang Keupula } \\
\text { Lhee Kecamatan Madat }\end{array}$ & 20.000 .000 \\
\hline 6 & Ingin Maju & $\begin{array}{c}\text { Gampong Matang Perlak } \\
\text { Kecamatan Pantee Bidari }\end{array}$ & 20.000 .000 \\
\hline 7 & Maju Bersama & $\begin{array}{c}\text { Gampong Matang Keupula } \\
\text { Dua Kecamatan Madat }\end{array}$ & 20.000 .000 \\
\hline & & Total & $\mathbf{1 5 0 . 0 0 0 . 0 0 0}$ \\
\hline
\end{tabular}

Sumber: DP3AKB Aceh Timur, 2019 
Selanjutnya, BPMPKS Kabupaten Aceh Timur pada Tahun 2011 melalu bidang pemberdayaan perempuan kembali memberi bantuan modal bergulir untuk 6 kelompok usaha perempuan miskin. Tabel 2 menunjuk kan kelompok-kelompok yang mendapatkan bantuan modal bergulir pada tahun 2011 .

Tahun 2013 BPMPKS Kabupaten Aceh Timur juga melalui bidang pemberdayaan perempuan kembali menggulirkan bantuan modal bergulir untuk 10 kelompok usaha perempuan miskin, dimana Tabel 3 menunjuk kan kelompok-kelompok yang mendapatkan bantuan modal bergulir pada tahun 2013. Terakhir, di tahun 2014 bantuan modal bergulir khusus kelompok usaha perempuan kembali diberikan kepada 5 kelompok oleh instansi pemerintahan, seperti ditunjukkan dalam Tabel 4.

Dari hasil penyaluran bantuan modal bergulir bagi kelompok usaha perempuan miskin di Kabupaten Aceh Timur oleh DP3AKB, dari tahun 2010-2016 ada 23 kelompok usaha perempuan yang telah mendapatkan bantuan modal bergulir tersebut dengan beraneka aktifitas yang digeluti seperti usaha pembuatan kue kering, anyaman tikar pandan, bandeng presto, ikan asin, usaha kelontong, jual beli rempah-rempah, pertanian dan lain-lain.

Dari 23 kelompok usaha perempuan yang mendapatkan bantuan modal usaha bergulir pemerintah melalui pihak DP3AKB Kabupaten Aceh Timur terdapat beberapa kelompok yang masih eksis melakukan aktifitas berkelompok seperti: kelompok Sinar Inong Tani, kelompok anyaman tikar pandan Bungong Cirih, Kelompok perempuan Baroe Phonna, kelompok usaha perempuan Ratana, kelompok usaha perempuan Srikandi dan kelompok usaha Bungong Jaroe. Kelompokkelompok tersebut hingga saat ini masih terus melakukan aktifitas kelompok. Sementara itu ada beberapa kelompok yang vakum beraktifitas diakibatkan oleh tidak sesuainya rencana kerja kelompok dengan pelaksanaan usaha. Kesemua permasalahan itu terungkap sewaktu pelaksanaan pelatihan penguatan kapasitas dalam perencanaan usaha be kelompok beberapa waktu yang lalu. Hal ini diakibatkan oleh beberapa hal, seperti:

a. 12 kelompok usaha perempuan miskin tidak memiliki tata kelola administrasi dan keuangan yang baik seperti: tidak memiliki buku kas, buku besar kelompok, buku pembelian dan penjualan, buku saku kelompok, iuran wajib dan bulanan, visi dan misi kelompok, rencana strategis kelompok, rencana kerja tahunan kelompok, analisa usaha, perencanaan usaha dan lain-lain.

b. 12 kelompok usaha perempuan miskin tidak memiliki tata kelola manajemen seperti Profil Kelompok, AD/ART Kelompok, Struktur Kerja Kelompok, Struktur Organisasi Kelompok, Legalitas kelompok. Sementara itu dua kelompok perempuan sudah memiliki tata kelola manajemen kelompok

c. 12 Kelompok usaha perempuan miskin tidak memiliki tata kelola aktifitas yang baik seperti tidak tercacatnya hasil penjualan, aktifitas yang dilakukan masih berfokus pemenuhan kebutuhan harian, tidak memiliki jadwal penjualan produk yang rutin

d. Ada beberapa kelompok yang tidak memiliki tenaga pemasaran yang khusus memasarkan produk-produk kelompok sehingga pola pemasaran masih bersifat konvensional serta memanfaatkan jaringan dan relasi keluarga atau teman terdekat. Disamping itu juga produk yang dihasilkan berdasarkan permintaan (based on request) bukan berdasarkan kebutuhan pasar (need on market) sehingga berdampak kepada minimnya permintaan dari pembeli.

e. Ada beberapa kelompok yang tidak memiliki jaringan kerja dengan SKPK terkait sehingga ketika ada permasalahan, kelompok tidak tahu bagaimana mengatasi permasalahan itu. Peran Dewan Kerajinan Nasional (Dekranas) Kabupaten Aceh Timur tidak maksimal untuk memperkuat keberadaan kelompok usaha perempuan. Selama ini Dekranas hanya terlibat ketika ada event/pameran usaha kerajinan baik di tingkat Kabupaten, Provinsi dan Nasional. 


\section{Hakikat Pemberdayaan Usaha Perempuan}

Pranarka dan Vidhandika (1996) menyebutkan bahwa pemberdayaan sebagai upaya memberikan kemampuan ataupun keberdayaan. Pada intinya, pemberdayaan perempuan adalah konsep atau paradigma baru pembangunan yang lebih mengaksentuasikan sifat-sifat "people centered, participatory empowering sustainable". Walaupun pengertiannya berbeda namun tetap mempunyai tujuan yang sama, yaitu untuk membangun daya, dengan mendorong, memotivasi, dan membangkitkan kesadaran akan potensi yang dimilikinya, serta adanya upaya mengembangkan kearah yang lebih baik. Pemberdayaan masyarakat bukanlah sekedar untuk memenuhi kebutuhan dasar atau menyediakan mekanisme pencegahan proses pemikiran lebih lanjut.

Paradigma pemberdayaan perempuan menuntut pendekatan yang tidak memposisikan perempuan sebagai obyek dari berbagai aksi pembangunan, tetapi harus menempatkan perempuan sebagai subyek kegiatan. Dengan pendekatan ini diharapkan akan lahir model-model pembangunan yang lebih partisipatif sehingga bentuk kontribusi perempuan tidak cukup hanya "ditandai" dalam uang, tenaga dan innatura lainnya, melainkan harus menghadirkan unsur inisiatif dan determinasi yang benar-benar tumbuh dari perempuan.

Dalam proses pemberdayaan perempuan diperlukan perencanaan yang tersusun secara matang dan langkah selanjutnya adalah mobilisasi sumberdaya yang diperlukan. Pada dasarnya penerapan nilai-nilai demokrasi pada program pemberdayaan perempuan sama dengan penerapan nilai-nilai demokrasi pada masyarakat umum, baik laki-laki maupun perempuan. Jadi pada intinya berupa dana (modal, sumberdaya manusia, teknologi dan organisasi atau kelembagaan).

\section{Strategi Pemberdayaan Perempuan}

Adi (2008) menyebutkan bahwa strategi pemberdayaan perempuan dinyatakan sebagai berikut:

a. Perempuan mempunyai peranan pada sektor domestik dan publik. Akses bagi perempuan untuk bekerja di luar rurnah dan kontrol perempuan atas pendapatan keluarga sangat kuat.

b. Perempuan menjalankan peranan produksi dengan menempati beberapa posisi dalam mata-rantai perdagangan sebagai pedagang hasil produksi segar, pengolah, pengemas, penyaji, dan penjual produk olahan. Posisi ini sebaiknya dipertahankan dalam upaya mendukung pengembangan daerah.

c. Faktor pendukung peningkatan peranan perempuan adalah kemauan kerjanya tinggi, dorongan keluarga cukup kuat, dan lokasi kegiatan merupakan obyek potensial yang membutuhkan aktivitas perempuan dalam perdagangan.

d. Kendala yang dihadapi rendahnya akses perempuan terhadap- sumberdaya modal, transportasi, dan informasi teknologi.

e. Tantangan terhadap kemajuan dan keberadaan perempuan dalam agribisnis di suatu daerah adalah masuknya pelaku pria dengan modal yang lebih kuat yang mampu memberikan penawaran yang lebih tinggi.

f. Strategi yang dapat dipilih perempuan untuk mempertahankan eksistensi dan posisinya adalah dengan usaha membentuk kelompok usaha bersama. Hal ini untuk meminimalkan persaingan di antara perempuan dan memperkuat modal usaha dalam kelompok.

g. Strategi perempuan untuk meningkatkan pendapatannya adalah dengan memperluas jangkauan pemasaran, memasuki segmen pasar yang lebih luas.

Menurut Nugroho (2008), tujuan dari program pemberdayaan perempuan adalah:

1. Meningkatkan kemampuan yang dimiliki kaum perempuan untuk melibatkan diri dalam program pembangunan, sebagai partisipasi aktif (subjek) agar tidak sekedar menjadi objek pembangunan seperti yang terjadi selama ini.

2. Meningkatkan kemampuan dari kaum perempuan dalam kepemimpinan, untuk meningkatkan posisi tawar-menawar dan keterlibatan dalam setiap pembangunan baik sebagai perencana, pelaksana, serta 
melaksanakan monitoring dan evaluasi kegiatan.

3. Meningkatkan kemampuan yang dimiliki kaum perempuan dalam mengelola usaha skala rumah tangga, industri kecil, maupun industri besar dalam upaya menunjang peningkatan kebutuhan rumah tangga, maupun untuk membuka peluang kerja produktif dan mandiri.

4. Meningkatkan peran dan fungsi organisasi perempuan di tingkat lokal sebagai wadah pemberdayaan kaum perempuan agar bisa terlibat aktif dalam program pembangunan di wilayah tempat tinggalnya.

\section{Pengertian Efektifitas}

Menurut Handayaningrat (2002), efektifitas adalah pengukuran dalam arti tercapainya tujuan yang telah ditentukan sebelumnya. Hal serupa juga dinyatakan oleh Sigit (2003), bahwa efektivitas adalah ukuran sejauh mana tujuan organisasi dapat tercapai.

Pendapat ini sesuai dengan pendapat Mathis (2002) yang mengatakan bahwa efektivitas adalah ukuran keberhasilan suatu organisasi dalam usaha mencapai tujuan organisasi yang telah ditetapkan. Kegiatan operasional dikatakan efektif apabila proses kegiatan tersebut mencapai tujuan dan sasaran akhir kebijakan.

Sementara itu, pendapat Steers (2001) bahwa efektivitas merupakan suatu tingkatan kemampuan milik organisasi untuk dapat melaksanakan seluruh tugastugas pokoknya atau pencapaian sasarannya. Pernyataan Steers menegaskan bahwa efektivitas adalah tujuan akhir dari suatu organisasi. Organisasiorganisasi yang rasional, akan mengarahkan segala tindakannya dalam mencapai tujuan yang diinginkan dan ditetapkan organisasi.

Georgopolous dan Tannembaum (2005) mengemukakan bahwa efektivitas ditinjau dari sudut pencapaian tujuan, dimana keberhasilan suatu organisasi harus mempertimbangkan bukan saja sasaran organisasi tetapi juga mekanisme mempertahankan diri dalam mengejar sasaran. Dengan kata lain, penilaian efektivitas harus berkaitan dengan mesalah sasaran maupun tujuan.
Bila suatu tujuan dan sasaran dapat tercapai tepat pada waktunya, maka program tersebut dikatakan efektif. Namun sebaliknya, bila tujuan dan sasaran tidak dapat tercapai tepat pada waktunya, maka program tersebut dikatakan tidak efektif. Bila dilihat dari aspek keberhasilan pencapaian tujuan, maka efektivitas berfokus pada tingkat pencapaian terhadap tujuan atau sasaran yang telah ditetapkan sebelumnya.

Handoko (2008) mengatakan bahwa efektivitas merupakan kemampuan untuk memilih tujuan yang tepat atau peralatan yang tepat untuk mencapai tujuan yang telah ditetapkan. Tingkat pelayanan dan derajat kepuasan masyarakat merupakan salah satu ukuran efektivitas. Ukuran ini tidak mempertimbangkan berapa biaya, tenaga dan waktu yang digunakan di dalam memberikan pelayanan, tetapi lebih menitikberatkan pada tercapainya tujuan organisasi pelayanan publik. Bila ditinjau dari aspek ketepatan waktu, maka efektivitas adalah tercapainya berbagai sasaran yang telah ditentukan sebelumnya tepat pada waktunya dengan menggunakan sumber-sumber tertentu yang sudah dialokasikan untuk berbagai kegiatan.

Selanjutnya bila ditinjau dari aspek manfaat, maka Steers (dalam Zainun, 2000) mendefenisikan efektivitas sebagai suatu usaha untuk mencapai suatu keuntungan manfaat dalam organisasi dengan segala cara. Ia menekankan bahwa semakin besar keuntungan yang diperoleh organisasi, maka organisasi itu semakin efektif.

Bila ditinjau dari hasil yang dicapai, Sarwoto (2003) mengatakan efektivitas sebagai sesuatu yang berhasil guna yaitu pelayanan baik atau mutu dan kegunaannya benar-benar sesuai dengan kebutuhan. Secara rinci dapat dikatakan bahwa aktivitas seseorang atau organisasi dikatakan efektif apabila aktivitas atau perbuatan tersebut menimbulkan akibat sebagaimana yang dikehendaki atau direncanakan.

Upaya mengevaluasi jalannya suatu kelompok usaha, dapat dilakukan melalui konsep efektivitas. Konsep ini adalah salah satu faktor untuk menentukan apakah perlu dilakukan perubahan secara signifikan 
terhadap bentuk dan manajemen organisasi atau tidak. Dalam hal ini, efektivitas merupakan pencapaian tujuan organisasi melalui pemanfaatan sumber daya yang dimiliki secara efisien, ditinjau dari sisi masukan (input), proses, maupun keluaran (output). Dalam hal ini, yang dimaksud sumber daya meliputi ketersediaan personil, sarana dan prasarana serta metode dan model yang digunakan. Suatu kegiatan dikatakan efisien apabila dikerjakan dengan benar dan sesuai dengan prosedur sedangkan dikatakan efektif bila kegiatan tersebut dilaksanakan dengan benar dan memberikan hasil yang bermanfaat.

\section{Ukuran Efektifitas}

Kriteria ataupun ukuran mengenai pencapaian tujuan secara efektif atau tidak, sebagaimana dikemukakan oleh Siagian (2000), yaitu:

a. Kejelasan tujuan yang hendak dicapai, hal ini dimaksudkan supaya karyawan dalam pelaksanaan tugas mencapai sasaran yang terarah dan tujuan organisasi dapat tercapai.

b. Kejelasan strategi pencapaian tujuan, telah diketahui bahwa strategi adalah "pada jalan" yang diikuti dalam melakukan berbagai upaya dalam mencapai bentukbentuk sasaran yang ditentukan agar para implementer tidak tersesat di dalam pencapaian tujuan organisasi.

c. Proses analisis dan perumusan kebijakan yang mantap, berkaitan dengan tujuan yang hendak dicapai dan strategi yang telah ditetapkan artinya kebijakan harus mampu menjembatani tujuan dengan usaha pelaksanaan kegiatan operasional.

d. Perencanaan yang matang, pada hakekatnya berarti memutuskan sekarang apa yang dikerjakan oleh organisasi di masa depan.

e. Penyusunan program yang tepat suatu rencana yang baik masih perlu dijabarkan dalam program-program pelaksanaan yang tepat sebab apabila tidak, para pelaksana akan kurang memiliki pedoman bertindak dan bekerja.

f. Tersedianya sarana dan prasarana kerja, salah satu indikator efektivitas organisasi adalah kemamapuan bekerja secara produktif. Dengan sarana dan prasarana yang tersedia dan mungkin disediakan oleh organisasi.

g. Pelaksanaan yang efektif dan efisien, bagaimanapun baiknya suatu program apabila tidak dilaksanakan secara efektif dan efisien maka organisasi tersebut tidak akan mencapai sasarannya, karena dengan pelaksanaan organisasi semakin didekatkan pada tujuannya.

h. Sistem pengawasan dan pengendalian yang bersifat mendidik mengingat sifat manusia yang tidak sempurna maka efektivitas organisasi menuntut terdapatnya sistem pengawasan dan pengendalian.

\section{Pendekatan terhadap Efektifitas}

Pendekatan efektivitas dilakukan dengan acuan berbagai bagian yang berbeda dari lembaga, dimana lembaga mendapatkan input atau masukan berupa berbagai macam sumber dari lingkungannya. Kegiatan dan proses internal yang terjadi dalam lembaga mengubah input menjadi output atau program yang kemudian dilemparkan kembali pada lingkungannya. Menurut Putra (2001), pendekatan terhadap efektivitas adalah:

1. Pendekatan Sasaran (Goal Approach), yaitu pendekatan ini mencoba mengukur sejauh mana suatu lembaga berhasil merealisasikan sasaran yang hendak dicapai. Pendekatan sasaran dalam pengukuran efektivitas dimulai dengan identifikasi sasaran organisasi dan mengukur tingkatan keberhasilan organisasi dalam mencapai sasaran yang hendak dicapai.

2. Pendekatan Sumber (System Resource Approach), yaitu pendekatan sumber mengukur efektivitas melalui keberhasilan suatu lembaga dalam upaya mendapatkan berbagai macam sumber yang dibutuhkan. Suatu lembaga harus dapat memperoleh berbagai macam sumber dan juga memelihara keadaan dan system agar dapat menjadi efektif. Pendekatan ini didasarkan pada teori mengenai keterbukaan sistem suatu lembaga terhadap lingkungannya, karena lembaga mempunyai hubungan yang merata dalam lingkungannya dimana 
dari lingkungan diperoleh sumber-sumber yang terdapat pada lingkungan seringkai bersifat langka dan bernilai tinggi.

3. Pendekatan Proses (Internal Process Approach), yaitu pendekatan proses menganggap sebagai efisiensi dan kondisi kesehatan dari suatu lembaga internal. Pada lembaga yang efektif, proses internal berjalan dengan lancer dimana kegiatan bagian-bagian yang ada berjalan secara terkoordinasi. Pendekatan ini tidak memperhatikan lingkungan melainkan memusat kan perhatian terhadap kegiatan yang dilakukan terhadap sumber-sumber yang dimiliki lembaga, yang menggambarkan tingkat efisiensi serta kesehatan lembaga.

4. Pendekatan Integratif (Integrative Approach), dimana pendekatan ini merupakan gabungan dari ketiga pendekatan diatas yang muncul sebagai akibat adanya kelemahan dan kelebihan masing-masing pendekatan.

\section{METODE PENELITIAN}

Penelitian ini menggunakan metode deskriptif yang bersifat kualitatif melalui focus group discussion (FGD), pengumpulan data, informasi, catatan lapangan dan dokumentasi kegiatan yang yang dilakukan oleh DPPKB terhadap kelompok usaha perempuan miskin penerima manfaat modal bergulir. Sampel penelitian ini adalah 8 (delapan) kelompok usaha perempuan miskin penerima modal bergulir dari instansi terkait.

Instrumen penelitian adalah alat atau fasilitas yang digunakan oleh peneliti dalam mengumpulkan data agar pekerjaannya lebih mudah dan hasilnya lebih baik. Dengan demikian, instrumen penelitian yang digunakan untuk memperoleh data. Instrumen yang dilakukan di dalam penelitian ini yaitu observasi, data terpilah, dan wawancara. Masing-masing instrumen itu dikembangkan berdasarkan kisi-kisi, sedangkan analisa data dilakukan dengan analisa kualitatif.

Teknik analisis data dalam penelitian secara lengkap menggunakan tiga alur kegiatan secara bersamaan, yaitu Tabulasi Data, Penyajian Data, serta Penyimpulan dan Data.

\section{HASIL ANALISIS}

\section{Observasi Lapangan}

Dalam kegiatan observasi ini, tim peneliti melihat pencatatan adminitrasi dan keuangan kelompok, buku pencatatan produksi, buku neraca penjualan produk, dengan maksud untuk mengetahui tingkat keaktifan kelompok dalam pencatatan administrasi dan keuangan. Selain melihat pencatatan adminitrasi dan keuangan dari kelompok sasaran, tim peneliti juga melakukan wawancara singkat dengan ketua dan anggota kelompok sasaran untuk menggali informasi berkenaan dengan modal usaha bergulir yang diberikan oleh DP3AKB Aceh Timur kepada beberapa kelompok usaha perempuan miskin di kabupaten Aceh Timur.

\section{FGD dengan Kelompok Usaha Perempuan}

Hasil FGD pada kelompok "Bunga Kasturi” tanggal 25 Juni 2018 bersama dengan ketua kelompok dapat analisis bahwa modal bergulir yang diberikan oleh DP3AKB sebanyak Rp. 70.000.000 pada tahun 2011 dan Rp. 25.000.000 pada tahun 2013. Terindetifikasi juga proses pengembalian modal usaha yang macet, kesalahan dalam penentuan jenis usaha, restrukturisasi kepengurusan, sepinya akses pemasaran produk dan peruntukan modal usaha yang tidak sesuai dengan kebutuhan. Hingga saat ini, modal usaha yang diberikan oleh dinas terkait secara langsung berdampak bagi peningkatan usaha yang dilakukan kelompok, misalnya menambah pendapatan bagi keluarga serta bertambahnya anggota kelompok. Adapun salah satu kelemahan yang ada pada kelompok ini adalah tidak adanya pencatatan keuangan dan administrasi kelompok, kelompok tidak memiliki buku kas, buku saku anggota, buku pencatatan produk serta perencanaan usaha (business plan).

Hasil FGD pada Kelompok Usaha Perempuan "SRIKANDI" Gampong Julok Tunong dapat dianalisis bahwa kelompok ini mendapatkan modal usaha bergulir dari BPMPKS Aceh Timur sebesar Rp. 25.000.000 pada tahun 2013. Sebelum modal usaha diberikan oleh dinas terkait, kelompok ini telah mendapatkan pelatihan berupa 
penyusunan business plan yang akan dijalankan kelompok. Selain itu, kelompok ini juga mendapatkan pelatihan pembukuan, administrasi, advokasi, komunikasi dan fasilitasi. Saat ini kelompok ini memfokuskan kegiatan pada simpan pinjam yang merupakan lanjutan dari program PNPM-Mandiri Perdesaan, dimana usaha simpan pinjam telah berkembang baik terutama dari aspek jumlah anggota maupun omzet penjualan. Modal usaha bergulir yang dipinjamkan kelompok telah dikembalikan kepada BPMPKS Aceh Timur pada tahun 2014.

Hasil FGD pada Kelompok Usaha Perempuan "Bungong Seuke" tanggal 9 Juli 2018 di Gampong Matang Gleum Kecamatan Peureulak dapat dianalisis bahwa kelompok ini mendapatkan bantuan modal usaha sebesar Rp. 60.700.000 setelah mendapatkan program pelatihan administrasi, perencanaan usaha dan keuangan kelompok oleh dinas terkait bersama tim teknis dari LP2K, PINBIS dan Universitas Samudra. Hasil temuan dalam FGD terlihat beberapa kelemahan pada kelompok ini seperti tidak adanya pencatatan keuangan dan administrasi kelompok, kelompok tidak memiliki buku kas, buku saku anggota dan buku pencatatan produk. Pembagian modal usaha yang diberikan tidak sesuai peruntukkan (digunakan untuk hal yang bersifat konsumtif), modal usaha yang diberikan habis terpakai oleh ketua kelompok padahal anggota kelompok telah melunasi peminjaman modal usaha itu.

Hasil FGD pada kelompok Usaha Perempuan "Baro Phonna" di Gampong Teupin Pukat Kecamatan Nurussalam Kabupaten Aceh Timur dapat dianalisis bahwa kelompok ini mendapatkan modal usaha bergulir dari BPMPKS Aceh Timur sebesar Rp. 60.700 .000 pada tahun 2010 dan Rp. 25.000.000 pada tahun 2013. Selain mendapatkan modal usaha bergulir dari DP3AKB Aceh Timur, kelompok ini juga mendapatkan modal bergulir dari PNPM-MP tahun 2017 sebesar Rp. 95 juta. Kelompok ini memfokuskan kegiatan pada pembuatan bandeng presto, SPP dan usaha kelontong. Saat ini kegiatan usaha ini telah mendatangkan keuntungan bagi kelompok terutama untuk usaha kelontong dan penjualan bensin. Dari aspek administrasi dan penatausahaan keuangan, kelompok usaha "Baro Phonna" memiliki buku pencatatan administrasi dan keuangan kelompok. Salah satu kendala yang dialami oleh kelompok saat ini adalah kurangnya monev yang dilakukan oleh dinas terkait, Tidak adanya pendampingan intens dari dinas terkait terhadap kegiatan usaha kelompok dan kurangnya penjualan produk yang dihasilkan oleh kelompok terutama untuk usaha bandeng presto akibat dari sepinya peminat atau calon pembeli. Hasil telaah dokumen memperlihatkan kelompok perempuan "Baro Phonna" telah menyelesaikan pengembalian modal usaha bergulir yang diberikan oleh dinas terkait dengan jangka waktu 30 bulan sesuai dengan perjanjian antara kelompok dan dinas terkait.

Hasil FGD pada kelompok Usaha Perempuan "Bungong Jaroe" dilakukan pada tanggal tanggal 18 Juli 2018 di Gampong Bukit Seuleumak Kecamatan Sungai Raya Kabupaten Aceh Timur dapat dianalisis bahwa kelompok ini mendapatkan bantuan modal usaha bergulir dari BPMPKS Aceh Timur di tahun 2011 sebesar Rp. 25.000.000 dan tahun 2013 sebanyak Rp. 25.000.000. Modal usaha bergulir yang diberikan di pergunakan untuk kegiatan pembuatan kue kering dan usaha kelontong. Pembuatan kue kering melibatkan remaja putri dan putus sekolah yang ada di gampong itu sehingga mampu menghasilkan pendapatan bagi anggota kelompok. Jenis kue kering yang dihasilkan oleh kelompok umumnya kue kering tradisional khas aceh seperti bhoe, kekarah, dan lain-lain.

Hasil FGD pada Kelompok Usaha Perempuan "Sinar Inong Tani (SITAG)" pada tanggal 21 Juli 2018 di Gampong Alue Gadeng Kecamatan Birem Bayeun Kabupaten Aceh Timur dapat dianalisis bahwa kelompok ini mendapatkan bantuan modal usaha bergulir dari BPMPKS Aceh Timur pada tahun 2010 sebesar Rp. 60.700 .000 serta Rp. 20.000.000 pada tahun 2014. Modal usaha bergulir yang diberikan dipergunakan untuk kegiatan SPP (Simpan Pinjam Perempuan), Kedai kelontong dan Pembuatan 
Kue Kering. Di awal pengajuan modal usaha kelompok SITAG telah menyusun perencanaan usaha (business plan) sewaktu pembekalan bagi kelompok penerima modal usaha bergulir bersama tim teknis dari LP2K, Pinbis dan Universitas Samudra.

Hasil FGD pada Kelompok Usaha Perempuan "Bungong Chirih" pada tanggal 24 Juli 2018 di Gampong Matang Gleum Kecamatan Peureulak Kabupaten Aceh Timur dapat dianalisis bahwa kelompok ini mendapatkan modal usaha bergulir dari BPMPKS Aceh Timur sebesar Rp. 20.000.000 pada tahun 2014. Modal yang diberikan oleh DP3AKB Aceh Timur diperuntukkan untuk modal usaha terhadap 5 (lima) orang anggota kelompok sesuai dengan usulan proposal yang diajukan oleh kelompok tersebut kepada dinas terkait. Kelompok ini memfokuskan kegiatan pada pembuatan anyaman tikar, kotak tisu, tas, kotak alat tulis, sarung bantal dan lain-lain. Salah satu kendala yang dialami oleh kelompok saat ini adalah modal bergulir yang diberikan kelompok kepada anggota kelompok belum dikembalikan hingga saat ini kepada ketua kelompok sehingga ketua kelompok terpaksa menutupi proses pengembalian modal itu, Ketua kelompok tidak melakukan tanggung renteng bagi anggota kelompok yang menunggak pengembalian modal usaha bergulir. Akibatnya modal tersebut menjadi macet dikarenakan lemahnya mekanisme pengembalian modal bergulir yang tidak tertuang dalam berita acara pengembalian modal usaha bergulir. Permasalahan yang dialami oleh kelompok juga diakibatkan oleh tidak adanya monev oleh dinas terkait.

Hasil FGD pada kelompok usaha perempuan "RATANA" pada tanggal 24 Juli 2018 di Gampong Kuala Geulumpang Kecamatan Julok Kabupaten Aceh Timur dapat dianalisis bahwa kelompok ini telah mendapatkan modal usaha bergulir sebesar Rp. 60.700.000 pada tahun 2010 serta Rp. 25.000.000 pada tahun 2013. Keseluruhan modal yang dipinjamkan dari BPMPKS Aceh Timur telah di lunasi oleh kelompok tersebut. Jangka waktu pengembalian modal bergulir tersebut adalah 18 bulan sesuai kesepakatan di tingkat kelompok. Saat ini kelompok memfokuskan kegiatan pada SPP (usaha simpan pinjam), kedai kelontong dan pembelahan ikan. Kegiatan usaha ini telah mendatangkan keuntungan bagi kelompok dan menarik minat pasar terutama untuk usaha pembelahan ikan. Khusus untuk usaha pembelahan ikan dikerjakan oleh unit usaha dibawah kendali kelompok Ratana. Usaha ini dikelola oleh salah satu anggota kelompok dengan sistem bagi keuntungan (pembagian persentase keuntungan). Kelompok Ratana meminjamkan modal usaha kepada salah satu anggota kelompok dan anggota kelompok mengelola modal usaha tersebut dengan membeli peralatan produksi dan menyewa tempat produksi. Produk usaha pembelahan ikan telah dijual diluar kabupaten Aceh Timur dalam bentuk kemasan.

\section{KESIMPULAN}

Berdasarkan hasil yang diperoleh dari penelitian tentang Effektifitas Pemberian Modal Usaha Bergulir DP3AKB Aceh Timur dengan studi kasus pada Kelompok Usaha Perempuan Miskin di Kabupaten Aceh Timur, dapat disimpulkan beberapa hal.

Pertama, dinyatakan bahwa faktor penyebab tidak dikembalikannya modal usaha bergulir itu dikarenakan beberapa sebab seperti: usaha yang dijalankan tidak sesuai dengan business plan yang disusun sewaktu pembekalan dilakukan oleh dinas terkait, terbatasnya akses pemasaran produk, tidak adanya promosi produk yang dilakukan oleh kelompok, tidak adanya pendampingan intens dari DP3AKB terhadap kelompok penerima modal usaha bergulir, tidak adanya monitoring dan evaluasi terhadap pelaksanaan program oleh dinas terkait, belum adanya standar operasional prosedur (SOP) terkait pengelolaan modal usaha bergulir, belum adanya kesadaran kritis bagi kelompok untuk mengembalikan modal usaha itu, dan lemanhnya SDM pada kelompok itu.

Kedua, dari hasil wawancara dan FGD yang dilakukan terhadap beberapa kelompok sasaran terungkap bahwa pemberian modal usaha bergulir untuk pihak kelompok usaha perempuan miskin efektif bagi peningkatan 
kesejahteraan kelompok, bertambahnya pendapatan yang didapatkan oleh anggota kelompok meningkat paska pemberian modal bergulir, bertambahnya omzet pendapatan dan anggota kelompok, meningkatnya pengetahun kelompok tentang teknik fasilitasi, teknik komunikasi, teknik advokasi, penatausahaan keuangan kelompok, penatausahaan administrasi kelompok, peran perempuan dalam peningkatan kesejahteraan masyarakat, Perhitungan neraca keuangan, terbentuknya unit usaha baru di kelompok seperti usaha jahit menjahit, penyewaan alat pesta dan lain-lain.

Kesimpulan berikutnya yaitu meskipun modal usaha bergulir yang diberikan oleh DP3AKB Aceh Timur efektif meningkatkan kesejahteraan bagi kelompok namun masih ditemukan beberapa kelemahan terutama berkenaan dengan aspek penatausahaan dan keuangan dari kelompok seperti lemahnya laporan pencatatan adminitrasi, pembukuan kelompok, pencatatan laba rugi, pencatatan produk yang dihasilkan, ketergantungan terhadap satu jenis produk, dan tidak adanya jaringan pemasaran diluar wilayah kerja.

Berdasarkan hasil penelitian dan pembahasan yang ada dalam penelitian ini, maka sejumlah rekomendasi dapat diberikan untuk dapat memajukan pengelolaan terhadap pemberian modal usaha bergulir. Pertama, dinas terkait sebaiknya membuat SOP tentang pengelolaan modal usaha bergulir kepada kelompok usaha perempuan miskin di Kabupaten Aceh Timur. Disamping itu juga adanya pendampingan teknis pada kelompok sasaran dengan melibatkan beberapa stakeholder seperti Universitas, LSM agar kelompok penerima modal usaha bergulir mampu menjalankan usahanya dengan benar.

Rekomendasi kedua adalah adanya monitoring dan evaluasi (monev) secara periodik terhadap kelompok usaha perempuan penerima modal usaha bergulir dengan maksud untuk mengetahui sejauhmana usaha itu dijalankan, kendala dan permasalahan yang dialami kelompok serta peningkatan SDM kelompok.

Ketiga, direkomendasikan untuk segera dilakukan pembentukan kelompok kerja (POKJA) yang berperan untuk memantau perkembangan usaha yang dijalankan oleh kelompok dan mengawasi aktifitas kelompok.

\section{DAFTAR PUSTAKA}

Adi, I.R. 2008. Intervensi Komunitas Pengembangan Masyarakat Sebagai Upaya Pemberdayaan Masyarakat. Jakarta: PT. RajaGrafindo Persada.

Badan Pusat Statistik Kabupaten Aceh Timur. 2015. Aceh Timur dalam Angka Tahun 2014. BPS Aceh.

Buchari, Z. 2000. Manajemen dan Motivasi. Jakarta: PT. Balai Aksara.

Cahyat. A. 2004. Bagaimana Kemiskinan di ukur? Beberapa Model Perhitungan Kemiskinan di Indonesia. Poverty dan Decentralization Project CIFOR (Center for International Forestry Research). BMZ (Bundesministerum fur Wirtschaftliche Zusammenarbiet und Entwicklung), November.

Chairunnisa, Suwendra, I.W. dan Susila, G.P.A.J. 2016. Efektivitas Program Dana Pinjaman Bergulir PNPM Mandiri Perkotaan dalam Meningkatkan Pendapatan Masyarakat. Jurnal Bisma Universitas Pendidikan Ganesha. Vol. 4, No. 1.

Dwidjowijoto, R.N. 2006. Kebijakan Publik untuk Negara-Negara Berkembang. Jakarta: PT. Elex Media Komputindo.

Farida, I. 2011. Efektivitas Program Dana Bergulir Syariah bagi Peningkatan Akses Keuangan KJKS/BMT dalam rangka Memperkuat UKM. Skripsi. Jakarta: Program Studi Muamalat. Universitas Islam Negeri Syarif Hidayatullah.

Georgopolous dan Tannembaum. 2005. Efektivitas Organisasi. Jakarta: Erlangga.

Handayaningrat, S. 2002. Pengantar Studi Ilmu Administrasi dan Manajemen, Jakarta: Haji Masagung.

Handoko, T.H. 2008. Manajemen Personalia dan Sumber Daya Manusia. Yogyakarta: BPFE. 
Jariah, A., Masjaya dan Djumadi. 2016. Evaluasi Penyaluran Bantuan Kredit Bergulir pada Usaha Kecil dan Menengah di Kecamatan Tering Kabupaten Kutai Barat. Jurnal Administrative Reform. Vol. 4, No. 1, hal. 1-12.

Mathis, R.L. dan Jackson, J.H. 2002. Manajemen Sumber Daya Manusia. Salemba Empat: Jakarta.

Maulidyah, R.H. 2014. Efektivitas Pinjaman Dana Bergulir PNPM (Program Nasional Pemberdayaan Masyarakat) Mandiri Perkotaan terhadap Masyarakat Kurang Mampu. Skripsi. Malang: Jurusan Ilmu Ekonomi. Universitas Brawijaya.

Pranarka, A.M.W. dan Moeljarto, V. 1996. Pemberdayaan (Empowerment). dalam Onny S. Prijono dan A.M.W Pranarka (eds). Pemberdayaan: Konsep, Kebijakan dan Implementasi. Jakarta: CSIS, hal.44-46.

Puspitassari, C.M. 2016. Studi Efektivitas Dana Bergulir pada Usaha Mikro di Kota Kediri. Skripsi. Kendari: Jurusan Ilmu Ekonomi. Universitas Halu Oleo.

Rahmatika. 2011. Analisis Efektivitas Program Pinjaman Dana Bergulir pada Unit Pengelola Kegiatan (UPK) PNPM Mandiri dan Kelompok Simpan Pinjam Perempuan (SPP) di Kecamatan Situjuh LimoNagari Kabupaten Lima Puluh Kota Tahun 2008-210. Skripsi. Padang: Program Studi Manajemen. Universitas Andalas.

Rencana Pembangunan Jangka Menengah (RPJM) Kabupaten Aceh Timur Tahun 2012-2017.

Sarwoto. 2003. Dasar-Dasar Organisasi dan Manajemen, Jakarta: Ghalia Indonesia.

Siagian, S.P. 2000. Filsafat Administrasi. Jakarta: Gunung Agung.
Siregar, J. 2014. Analisis Efektivitas Pengembalian Dana Pinjaman Kelompok Simpan Pinjam Perempuan (SPP) dalam Program PNPM-MP di Kecamatan Argamakmur. Skripsi. Bengkulu: Jurusan Ekonomi Pembangunan Universitas Bengkulu.

Steers, R.M. 2001. Efektifitas Organisasi. Cetakan Kedua. Jakarta: Erlangga.

Taufiq, Agus H. 2015. Analisis Efektivitas Program Pinjaman Dana Bergulir Pada Unit Pengelolaan Kegiatan (UPK) PNPM Mandiri di Kecamatan Mojowarno Kabupaten Jombang Tahun 2014. Jurnal Bisnis dan Manajemen Islam. Vol. 3, No. 1, hal. 192-212.

Trisnojuwono, A., Hubeis, A.V.S. dan Cahyadi, E.R. 2017. Analisis Strategi Pembiayaan Usaha Mikro dan Kecil melalui Dana Bergulir pada Lembaga Pengelola Dana Bergulir. Manajemen IKM: Jurnal Manajemen Pengembangan Industri Kecil Menengah. Vol. 12, No. 2, hal. 178-186.

Wardani, R.K. 2012. Efektivitas Program Pinjaman Bergulir terhadap Kesejahteraan Masyarakat. Skripsi. Surakarta: Program Studi Ilmu Komunikasi. Universitas Muhammadiyah.

Widiana, I.K.A. 2015. Evaluasi Program Bantuan Dana Bergulir pada Empat Koperasi Penerima Program Bantuan Dana Bergulir di Kabupaten Buleleng Tahun 2014. Jurnal Pendidikan Ekonomi. Vol. 9, No. 1, hal. 830-842.

Yusrianti, H. 2011. Efektivitas Penyaluran dan Monitoring Pinjaman Bergulir Program Nasional Pemberdayaan Masyarakat (PNPM) Mandiri Perkotaan di Kota Palembang. Prosiding Seminar Nasional Hasil Penelitian 2011. Hal. 845-856. 